\title{
Academic and sport achievements of the physical culture and sports university students
}

\author{
Ihor Zanevskyy ${ }^{\mathrm{ACE}}$, Lyudmyla Zanevska ${ }^{\mathrm{BDE}}$ \\ Lviv State University of Physical Culture, Ukraine
}

Authors' Contribution: A - Study design; B - Data collection; C - Statistical analysis; D - Manuscript Preparation; E- Funds Collection

\begin{tabular}{|c|c|}
\hline \multicolumn{2}{|l|}{ Abstract } \\
\hline Purpose: & $\begin{array}{l}\text { It is widely used a paradigm about the interdependence between the academic and sport achievements } \\
\text { of students. The aim of this research was to create a model for studying relationships between academic } \\
\text { and sport achievements of the sports and physical culture university students. }\end{array}$ \\
\hline Material: & $\begin{array}{l}\text { Totally } 259 \text { ( } 168 \text { male and } 91 \text { female) bachelor students of } 18-23 \text { years old studied Physical Culture and } \\
\text { Sports were involved into the investigation. All the students were good healthy, and they participated in } \\
\text { the sport training and competitions, according to the common program. Interdependence between the } \\
\text { semester control scores and scores of the sport achievements were studied in the frames of correlation } \\
\text { models of parameter and non-parameter statistics. Distribution of scores was studied using Kolmogorov } \\
\text { - Smirnov method. One-way ANOVA for repeated measures was used to determine differences between } \\
\text { students' scores and educational disciplines' scores. }\end{array}$ \\
\hline Results: & $\begin{array}{l}\text { Almost non-significant weak interdependence between results of semester control and sport } \\
\text { achievements was noticed }\left(p>0.05,0.174 \leq r_{s} \leq 0.284\right) \text {. There were no statistically significant and tight } \\
\text { correlation between semester control scores of educational disciplines and corresponding sport } \\
\text { achievements scores }\left(\left|r_{s}\right| \leq 0.376\right) \text {. Contrary, in } 73 \% \text { of educational disciplines pairs the semester control } \\
\text { scores showed significant and tight correlation }(p<0.001,0.385 \leq r \leq 0.895) \text {. }\end{array}$ \\
\hline Conclusions: & $\begin{array}{l}\text { A well-known paradigm about significant relationship between academic and sport achievements of } \\
\text { students was not confirmed with the results of this research and should be studied more profoundly. }\end{array}$ \\
\hline
\end{tabular}

\section{Introduction}

In the sports and physical culture pedagogy, there is a well-known paradigm regarding the academic and sport achievements. It is widely used an idea about the interdependence between the academic and sport achievements of students. Quantitative methods for assessment of the motivation factors for professional sport activity were developed regarding the problem [1]. The investigation of the relationship between academic and sport motivation orientations of the physical education college students led to a positive statistically significant result $[2,3]$. There is a positive correlation between the motivation of achievement and the tendency towards studying physical education [4, p. 432]. Sierra-Diaz et al. published a systematic review and meta-analysis of psychosocial factors related to physical education motivates students to practice physical activities and sports through models-based practice. They described implementation of cooperative learning, constraint-led approach, games-cantered approach, sport education model, hybridizations, autonomy-supportive climate and their impact on the students' motivation [5].

There are a lot of research on the problem of sport achievements motivation and physical education involvement. Burgueno et al. examined the influence of an intervention based on Sport Education Model, in comparison with traditional teaching model, on

(c) Ihor Zanevskyy, Lyudmyla Zanevska, 2021

doi:10.15561/26649837.2021.0304 motivational regulation in high school students in Physical Education class [6, p. 87]. Self-determined motivation and state of flow in an extracurricular program of small-sided games were studied [7] and adopting of a models-based approach to teaching physical education was investigated [8]. Corresponding research are based on the constraintled approach to sport and physical education pedagogy and spread a wide range of pupils and students in different ages [9]. Navarro-Paton et al. derived a relation between motivation and enjoyment in physical education classes in children from 10 to 12 years old [10]. Influence of a sport education season on motivational strategies in high school students taking into account a self-determination theory-based perspective was investigated by Medina et al. [11]. Kolovelonis and Goudas determine the relation of physical self-perceptions of competence, goal orientation, and optimism with students' performance calibration in physical education [12].

The way to increase the motor and sport competence among children was found using the contextualized sport alphabetization model $[13,14]$. Associations among basic psychological needs, motivation and enjoyment within Finnish physical education students were studied by Huhtiniemi et al. [15]. Hartwig et al. created a monitoring system to provide feedback on student physical activity during physical education lessons [16].

In all the presented above publications, academic and sport motivations orientations of students were studied using questionaries' methods. Academic motivation scale 
and sport motivation scale were applied to measure the data for correlation analysis. These results are useful and practical, but do not obtain a straight consideration of the paradigm about academic and sport achievements of students because they are subjective, i.e. produced by subjects. The results present what subjects know, what they want, plan, consider etc. Contrary, we did not find research operated with objective data measured academic and sport achievements of students. Such results should not be depended on the subjects, i.e. students.

Research hypothesis. There is a significant straight correlation between academic and sport achievements of the sports and physical culture university students.

Purpose. The aim of this research was to create a model for studying relationships between academic and sport achievements of the sports and physical culture university students.

\section{Material and Methods}

\section{Participants}

Totally 259 bachelor students of 18-23 years old studied Physical Culture and Sports were involved into the investigation. They were 168 male students with body length $177.2 \pm 4.7 \mathrm{~cm}$ and body mass $74.1 \pm 3.8$ $\mathrm{kg}(\mathrm{M} \pm \mathrm{SD})$ and 91 female students with body length $164.7 \pm 4.2 \mathrm{~cm}$ and body mass $61.2 \pm 3.1 \mathrm{~kg}$ ). All the students were good healthy, and they participated in the sport training and competitions, according the common program [17]. This study was approved in advance by Ethical Committee of Lviv State University of Physical Culture. Students voluntarily provided written informed consent before participating. The procedures followed were in accordance with the ethical standards of Helsinki Declaration on human experimentation.

\section{Procedure}

Results of the winter semester control of $2019-2020$ academic year were taken into consideration. Academic achievements were determined as scores of 100 points academic scale regarding all the educational disciplines $[18$, p. 2]. Sport achievements were determined as scores of 100 points sport scale [19, p. 4].

Statistical analysis

Interdependence between the semester control scores and scores of the sport achievements were studied in the frames of correlation models of parameter (Pearson [20]) and non-parameter (Spearman [21]) statistics. Statistical significance of correlation was determined using t-Student parameter. Distribution of scores was studied using Kolmogorov - Smirnov method [22]. One-way ANOVA for repeated measures was used to determine variations between students' scores and between educational disciplines' scores [23].

Statistical elaboration of scores was done using on-line package of computer programs Social Science Statistics [24] and Data Analysis Adon of MS Excel [25].

\section{Results}

Because sport scale scores did not meet normal distribution in all of the four years $(\mathrm{p} \leq 0.039)$, relationship between academic and sport scores was determined using Spearman correlation coefficient [21] (Table 1).

Between the semester control average scores and corresponding sport achievements scores, weak $\left(1^{\text {st }}, 2^{\text {nd }}\right.$, and $3^{\text {rd }}$ years) and very weak ( $4^{\text {th }}$ year) correlation was noticed $\left(0.174 \leq \mathrm{r}_{\mathrm{s}} \leq 0.284\right)$. On the second and fourth years, significance of correlation was low $(\mathrm{p}>0.165)$, and on the first year - a little beat lower than it is widely used $(\mathrm{p}>0.05)$. Only on the third year, quit weak significant correlation was noticed on the near sufficient level $\mathrm{p}=0.054$ (see table 1). Totally, on the four bachelor years, almost non-significance interdependence between results of the semester control and sport achievements was noticed. Besides the average scores, correlation analysis was done between sport achievements scores and separate educational disciplines scores (Table 2).

Statistically significant correlation between sport achievements scores and semester control scores was noticed for Kinesiology, Physiology of sports, and Biochemical basis of sports $(p<0.022)$. The tightness of correlation for these three educational disciplines was low (see Table 2). One can turn his attention to the clear superiority of the correlation tightness of sport achievements scores with scores of medicine and biology educational disciplines (Kinesiology, Physiology of sports, and Biochemical basis of sports) relatively the sport disciplines (Theory and methods of sports,

Table 1. Average score of the semester control / Scores of sport achievement

\begin{tabular}{lllll}
\hline \multirow{2}{*}{ Statistics* } & Year & $\mathbf{2}$ & $\mathbf{3}$ & $\mathbf{4}$ \\
\cline { 2 - 5 } & $\mathbf{1}$ & 52 & 64 & 43 \\
$\mathrm{n}$ & 48 & $98.0 / 60.0$ & $89.0 / 50.0$ & $93.0 / 50.0$ \\
$90^{\text {th }}$ percentile & $99.0 / 51.0$ & $90.0 / 30.0$ & $80.0 / 30.0$ & $87.0 / 20.0$ \\
$\mathrm{Me}$ & $91.5 / 30.0$ & $82.9 / 10.0$ & $66.0 / 20.0$ & $76.0 / 10.0$ \\
$10^{\text {th }}$ percentile & $81.8 / 0.0$ & $0.147 / 0.285$ & $0.162 / 0.245$ & $0.139 / 0.214$ \\
$\mathrm{D}$ & $0.255 / 0.253$ & $0.227 / 0.001$ & $\mathbf{0 . 0 7 9} / 0.001$ & $0.372 / 0.039$ \\
$\mathrm{p}(\mathrm{D})$ & $0.085 / 0.006$ & 0.203 & 0.263 & 0.174 \\
$\mathrm{r}_{\mathrm{s}}$ & 0.284 & 0.166 & $\mathbf{0 . 0 5 4}$ & 0.277 \\
$\mathrm{p}\left(\mathrm{r}_{s}\right)$ & 0.062 & & & \\
\hline
\end{tabular}

* $n$ - number, Me - median, D - Kolmogorov - Smirnov statistics, $p$ - significance; $r_{s}$ - Spearman coefficient 
Theory and methods of physical education, Introduction into specialty, Defence of the coaching practice, and Organization of physical culture).

Because the semester control disciplines scores distributions were rather similar to normal distribution ( $p \geq 0.079$, see Table 1), the analysis of relationships between scores of separate educational disciplines was undertaken using Pearson correlation model [20] (Tables 3-6).

Rather significant correlation $(0.001 \leq \mathrm{p}<0.01)$ on the second year was noticed between results of Psychology of sports and Theory and methods of sports $(p=0.004)$, results of Pedagogics and Theory and methods of sports $(p=0.001)$, and between results of Theory and methods of gymnastics and Theory and methods of sports $(\mathrm{p}=0.006$, see Table 4).

On the third year, fairly significant correlation was noticed between results of Foreign language and Economic theory $(\mathrm{p}=0.009)$. On the fourth year, significant correlation was noticed between results of Defence of the coaching practice and Economy of sports $(p=0.007$, see Table 5) and between scores of Organization of physical culture and Defence of the coaching practice $(\mathrm{p}=0.008$, see Table 6).

Statistically sufficient significance correlation $(0.01 \leq p<0.05)$ was noticed on the third year between scores of Foreign language and Theory and methods of physical education $(p=0.025)$, and on the fourth year - between results of Defence of the coaching practice and Common theory of the professional sports $(p=0.012)$. Statistically non-sufficient significance correlation $(\mathrm{p} \geq 0.05)$ was noticed between scores results of Defence of the coaching practice and Theory and methods of sports $(p=0.084)$, as well, as between results of Theory and methods of sports and Common theory of the professional sports $(p=0.309)$.

Totally, on all the bachelor years (see Tables 3-6), between semester control scores of educational disciplines in prevailing number comparisons (28 from 38 pairs) statistically high significance $(\mathrm{p}<0.001)$ of tight correlation $(0.385 \leq \mathrm{r} \leq 0.895)$ was revealed.

As a result of one-way ANOVA for repeated measures significant differences between individual students' scores and educational disciplines' scores were determined $(p<0.001)$. The biggest relative variation between semester control scores was noticed among educational disciplines in the first year (43.4\%): Theory and methods of sports, History of Ukraine, and Introduction into specialty, and the smallest - in the second year (17.5\%): Theory and methods of sports, Physiology of sports, Pedagogics, Theory and methods of track and field, and Theory and methods of gymnastics. The biggest relative variation between student's semester control scores was noticed in the second year $(82.5 \%)$ and the smallest - in the first $(56.6 \%)$

Table 2. Correlation between the educational disciplines scores semester control and sport achievements scores

\begin{tabular}{llll}
\hline Years & Educational disciplines & $\mathbf{r}_{s}$ & $\left.\mathbf{p}_{\mathbf{s}}\right)$ \\
\hline \multirow{2}{*}{1} & Theory and methods of sports & 0.283 & 0.051 \\
& Introduction into specialty & 0.123 & 0.404 \\
& Theory and methods of sports & 0.260 & 0.063 \\
\multirow{2}{*}{ Psychology } & Pedagogics & 0.022 & 0.875 \\
& Theory and methods of track and field & 0.045 & 0.751 \\
& Theory and methods of gymnastics & 0.074 & 0.600 \\
& Theory and methods of physical education & 0.096 & 0.500 \\
& Kinesiology & -0.022 & 0.861 \\
& Physiology of sports & 0.327 & 0.005 \\
& Biochemical basis of sports & 0.270 & 0.021 \\
& Defence of the coaching practice & 0.376 & 0.001 \\
& Theory and methods of physical education & 0.064 & 0.683 \\
& Organization of physical culture & -0.063 & 0.686 \\
\end{tabular}

Table 3. Correlation table of the educational disciplines scores on the semester control of $1^{\text {st }}$ year: $r$-Pearson $\backslash t$-Student

\begin{tabular}{llll}
\hline Educational disciplines & $\begin{array}{l}\text { Theory and methods of } \\
\text { sports }\end{array}$ & History of Ukraine & $\begin{array}{l}\text { Introduction } \\
\text { into specialty }\end{array}$ \\
\hline Theory and methods of sports & $\diamond$ & 4.268 & 3.716 \\
History of Ukraine & $0.492^{* * *}$ & $\diamond$ & 8.803 \\
Introduction into specialty & $0.442^{* * *}$ & $0.759 * * *$ & $\diamond$ \\
\hline
\end{tabular}

${ }^{\circ}=59, * * * p<0.001, t(0.001,57)=3.470$ 
Table 4. Correlation table of the educational disciplines scores on the semester control of $2^{\text {nd }}$ year: $r$-Pearson $\backslash t$-Student

\begin{tabular}{|c|c|c|c|c|c|}
\hline Educational disciplines & $\begin{array}{l}\text { Theory and } \\
\text { methods of } \\
\text { sports }\end{array}$ & $\begin{array}{l}\text { Physiology of } \\
\text { sports }\end{array}$ & Pedagogics & $\begin{array}{l}\text { Theory and } \\
\text { methods of } \\
\text { track and } \\
\text { field }\end{array}$ & $\begin{array}{l}\text { Theory and } \\
\text { methods of } \\
\text { gymnastics }\end{array}$ \\
\hline Theory and methods of sports & 0 & 2.960 & 3.344 & 4.522 & 2.860 \\
\hline Physiology of sports & $0.362 * *$ & 0 & 12.300 & 10.173 & 15.265 \\
\hline Pedagogics & $0.402 * *$ & $0.850 * * *$ & 0 & 7.911 & 10.722 \\
\hline $\begin{array}{l}\text { Theory and methods of track } \\
\text { and field }\end{array}$ & $0.511^{* * *}$ & $0.801^{* * *}$ & $0.720 * * *$ & 0 & 13.408 \\
\hline $\begin{array}{l}\text { Theory and methods of } \\
\text { gymnastics }\end{array}$ & $0.352 * *$ & $0.895^{* * *}$ & $0.815^{* * *}$ & $0.870 * * *$ & 0 \\
\hline
\end{tabular}

${ }^{\circ} \mathrm{n}=60, * * \mathrm{p}<0.01, * * * \mathrm{p}<0.001, \mathrm{t}(0.01,58)=2.663, \mathrm{t}(0.001,58)=3.466$

Table 5. Correlation table of the educational disciplines scores on the semester control of $3^{\text {rd }}$ year: $r$-Pearson $\backslash t$-Student

\begin{tabular}{|c|c|c|c|c|c|c|}
\hline Educational disciplines & Kinesiology & $\begin{array}{l}\text { Foreign } \\
\text { language }\end{array}$ & $\begin{array}{l}\text { Economic } \\
\text { theory }\end{array}$ & $\begin{array}{l}\text { Physiology } \\
\text { of sports }\end{array}$ & $\begin{array}{l}\text { Biochemical } \\
\text { basis of } \\
\text { sports }\end{array}$ & $\begin{array}{l}\text { Theory and } \\
\text { methods } \\
\text { of physical } \\
\text { education }\end{array}$ \\
\hline Kinesiology & 0 & 3.727 & 11.028 & 6.838 & 5.788 & 12.327 \\
\hline Foreign language & $0.385^{* * *}$ & 0 & 2.648 & 4.345 & 7.564 & 2.287 \\
\hline Economic theory & $0.777 * * *$ & $0.284 * *$ & $\diamond$ & 6.649 & 5.249 & 13.742 \\
\hline Physiology of sports & $0.607 * * *$ & $0.437 * * *$ & $0.597 * * *$ & 0 & 9.470 & 5.817 \\
\hline $\begin{array}{l}\text { Biochemical basis of } \\
\text { sports }\end{array}$ & $0.543 * * *$ & $0.646 * * *$ & $0.506 * * *$ & $0.727 * * *$ & 0 & 4.709 \\
\hline $\begin{array}{l}\text { Theory and methods of } \\
\text { physical education }\end{array}$ & $0.809 * * *$ & $0.248 *$ & $0.838 * * *$ & $0.545 * * *$ & $0.466 * * *$ & 0 \\
\hline
\end{tabular}

${ }^{\circ} \mathrm{n}=82,{ }^{*} \mathrm{p}<0.05,{ }^{* *} \mathrm{p}<0.01, * * * \mathrm{p}<0.001, \mathrm{t}(0.05,80)=1.990, \mathrm{t}(0.01,80)=2.639, \mathrm{t}(0.001,80)=3.416$

Table 6. Correlation table of the educational disciplines scores on the semester control of $4^{\text {th }}$ year: $r$-Pearson $\backslash t$-Student

\begin{tabular}{|c|c|c|c|c|c|}
\hline Educational disciplines & $\begin{array}{l}\text { Defence of } \\
\text { the coaching } \\
\text { practice }\end{array}$ & $\begin{array}{l}\text { Theory and } \\
\text { methods of } \\
\text { sports }\end{array}$ & $\begin{array}{l}\text { Organization } \\
\text { of physical } \\
\text { culture }\end{array}$ & $\begin{array}{l}\text { Common } \\
\text { theory of the } \\
\text { professional } \\
\text { sports }\end{array}$ & $\begin{array}{l}\text { Economy of } \\
\text { sports }\end{array}$ \\
\hline $\begin{array}{l}\text { Defence of the coaching } \\
\text { practice }\end{array}$ & 0 & 1.757 & 2.698 & 2.584 & 2.821 \\
\hline Theory and methods of sports & 0.229 & 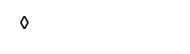 & 3.866 & 1.026 & 5.365 \\
\hline $\begin{array}{l}\text { Organization of physical } \\
\text { culture }\end{array}$ & $0.339 * *$ & $0.459 * * *$ & 0 & 7.797 & 10.268 \\
\hline $\begin{array}{l}\text { Common theory of the } \\
\text { professional sports }\end{array}$ & $0.326^{*}$ & 0.136 & $0.721 * * *$ & 0 & 4.477 \\
\hline Economy of sports & $0.353 * *$ & $0.583 * * *$ & $0.808 * * *$ & $0.513^{* * *}$ & 0 \\
\hline
\end{tabular}

${ }^{\circ} \mathrm{n}=58,{ }^{*} \mathrm{p}<0.05, * * \mathrm{p}<0.01, * * * \mathrm{p}<0.001, \mathrm{t}(0.05,56)=2.003, \mathrm{t}(0.01,56)=2.667, \mathrm{t}(0.001,56)=3.473$ 


\section{Discussion}

According to the aim of this research, a model for studying relationships between academic and sport achievements of the sports and physical culture university students was created using parametric and non-parametric correlation of scores in 100 points scales educational disciplines semester control and regarding sport achievements $[18,19]$. Unlike well-known models described sport motivations orientations of students based on the questioning $[26,27]$, the proposed in this paper model uses scores independent of subjective evaluation of students regarding their individual achievements.

It is interesting to notice that correlation tightness $\left(r_{s}=0.270-0.376, p \leq 0.021\right)$ of sport achievements scores with scores for medicine and biology educational disciplines (Kinesiology, Physiology of sports, and Biochemical basis of sports) was found significantly greater than corresponding correlation tightness $(p>0.05)$ for the sport educational disciplines (Theory and methods of sports, Theory and methods of physical education, Introduction into specialty, Defence of the coaching practice, and Organization of physical culture).

The model has very strong resolution because ANOVA for repeated measures showed significant differences as between individual students' scores and educational disciplines' scores as well ( $\mathrm{p}<0.001)$. It is will be useful for individual evaluation of academic and sport achievement of Physical Culture and Sports university students as well, as students of another specialities and students at preparatory schools [28, 29]. The model was created and evaluated using results of semester control a sample of male and female students because scales used in the model were intended to male students and female students ignoring gender differences. However, in well-known scientific publications sport motivations orientations of students were studied taking into consideration genders $[4,26]$. Therefore, influence of genders should be a research problem for future investigations of the proposed methods.

There were no statistically significant and tight correlation between semester control scores of educational disciplines and corresponding sport achievements scores $\left(\left|\mathrm{r}_{\mathrm{s}}\right| \leq 0.376\right)$. Contrary, in $73 \%$ of educational disciplines pairs the semester control scores showed significant and tight correlation $(\mathrm{p}<0.001,0.385 \leq \mathrm{r} \leq 0.895)$.

Use of the on-line package of computer programs Social Science Statistics [24] and Data Analysis Adon of MS Excel [25] computer packet as a mathematical instrument of studying relationship between semester control and sport achievements scores make possible to use this model for teachers of physical culture and coachers which are not familiar with mathematical modelling.

\section{Conclusions}

A research hypothesis regarding significant straight correlation between semester control scores of academic and sport achievements of the sports and physical culture university students was rejected on the sufficient statistical level $(\mathrm{p}>0.05)$. Therefore, a well-known paradigm in physical culture and sports about significant relationship between academic and sport achievements of students was not confirmed with the results of this research and should be studied more profoundly.

\section{Highlights}

There were no statistically significant and tight correlation between semester control scores of educational disciplines and corresponding sport achievements scores $\left(\left|\mathrm{r}_{\mathrm{s}}\right| \leq 0.376\right)$. Contrary, in $73 \%$ of educational disciplines pairs the semester control scores showed significant and tight correlation.

A well-known paradigm in physical culture and sports about significant relationship between academic and sport achievements of students was not confirmed with the results of this research and should be studied more profoundly.

One can turn his attention to the clear superiority of the correlation tightness of sport achievements scores with scores of medicine and biology educational disciplines $(p \leq 0.021)$ relatively the sport disciplines $(p>0.05)$.

\section{Acknowledgements}

The work was conducted in the frames of the scientific and research plan of Lviv State University of Physical Culture during 2016 - 2020 years. Authors thank Dean of Faculty of Physical Culture and Sports Lviv State University of Physical Culture Docent Ihor Ripak for support in accessing results of semester control and scores of sport achievements of bachelor students.

\section{Information on financial support}

The authors declare no financial support regarding this paper.

\section{Conflict of Interest}

The authors declare that there is no conflict of interest regarding this research.

\section{References}

1. Bondarenko MP. Assessment of the motivation factors for professional sport activity. Middle-East Journal of Scientific Research, 2013; 14 (9): 1221-1225. https://doi.org/10.5829/idosi.mejsr.2013.14.9.2227

2. Turkmen M. Investigation of the Relationship between Academic and Sport Motivation Orientations. Middle-East Journal of Scientific Research, 2013; 16 (7): 1008-1014. https://doi.org/10.5829/idosi.mejsr.2013.16.07.765
3. Turkmen M, Bozkus T, Altintas A. The relationship between motivation orientations and competitive anxiety in Bocce players: Does gender make a difference? Psychology and Behavioral Sciences, 2013; 2 (4): 162-168. https://doi.org/10.11648/j.pbs.20130204.12

4. Mahmoud MAAE. Preparatory school students' attitudes towards physical education lessons and its relationship to sport achievement motivation in Al Fayoum governorate. World Journal of Sport Sciences, 2012; 6 (4): 432-440. 
https://doi.org/10.5829/idosi.wjss.2012.6.4.1158

5. Sierra-DíazMJ, González-Víllora S, Pastor-Vicedo JC,LópezSánchez GF. Can We Motivate Students to Practice Physical Activities and Sports Through Models-Based Practice? A Systematic Review and Meta-Analysis of PsychosocialFactors Related to Physical Education. Front Psychol, 2019;10:2115. https://doi.org/10.3389/fpsyg.2019.02115

6. Aelterman N, Vansteenkiste M, Van-Keer, Van den Berghe L, De-Meyer J, Haerens L. Students' objectively measured physical activity levels and engagement as a function of between-class and betweenstudent differences in motivation toward physical education. J. Sport Exerc. Psychol. 2012; 34: 457-480. https://doi.org/10.1123/jsep.34.4.457

7. Carrasco-Beltran HJ, Reigal RE, Fernandez-Uribe S, Vallejo-Reyes F, Chirosa-Rios LJ. Self-determined motivation and state of flow in an extracurricular program of Small-Sided Games. An. Psicol. 2018; 34: 391-397. https://doi.org/10.6018/analesps.34.2.258621

8. Casey A, MacPhail A. Adopting a modelsbased approach to teaching physical education. Phys. Educ. Sport Pedag. 2018; 23: 294-310. https://doi.org/10.1080/17408989.2018.1429588

9. Renshaw I, Chow JY. A constraint-led approach to sport and physical education pedagogy. Phys. Educ. Sport Pedag. 2019; 24: 103-116. https://doi.org/10.1080/17408989.2018.1552676

10.Navarro-Paton R, Lago-Ballesteros J, Basanta-Camino S, Arufe-Giraldez V. Relation between motivation and enjoyment in physical education classes in children from 10 to 12 years old. J. Hum. Sport Exerc. 2018; 1: 1-11. https://doi.org/10.14198/jhse.2019.143.04

11.Medina-Casaubon $\mathrm{J}$, Burgueno $\mathrm{R}$. Influence of a sport education season on motivational strategies in high school students: a self-determination theorybased perspective. Ebm. Recide. 2017; 13: 153-166. https://doi.org/10.1186/1479-5868-8-78

12.Kolovelonis A, Goudas M. The relation of physical selfperceptions of competence, goal orientation, and optimism with students' performance calibration in physical education. Learn. Individ. Differ. 2018; 61: 77-86. https://doi.org/10.1016/j.lindif.2017.11.013

13.Gonzalez-Víllora S, Sierra-Diaz MJ, Pastor-Vicedo JC, Contreras-Jordán OR. The way to increase the motor and sport competence among children: the Contextualized Sport Alphabetization model. Front. Physiol. 2019; 10: 569. https://doi.org/10.3389/fphys.2019.00569

14.Gonzalez-Villora S, Evangelio C, Sierra-Diaz J, Fernandez-Rio J. Hybridizing Pedagogical models: a systematic review. Eur. Phys. Educ. Rev. 2018; 20: 1-19. https://doi.org/10.1177/1356336X18797363

15.Huhtiniemi M, Saakslahti A, Watt A, Jaakkola T. Associations among basic psychological needs, motivation and enjoyment within finnish physical education students. J. Sport Sci. Med. 2019; 18: 239-247.

16.Hartwig TB, Pozo-Cruz B, White RL, Sanders T, Kirwan M, Parker PD, et al. A monitoring system to provide feedback on student physical activity during physical education lessons. Scand. J. Med. Sci. Sports. 2019; 29: 1305-1312. https://doi.org/10.1111/sms.13438
17.Bachelor Educational Program. Speciality 017 "Physical Culture and Sports". [document on the Internet]. Accepted by Academic Board of Lviv State University of Physical Culture. 2016. [cited 2021 Jan 12]. Available from: https:// www.ldufk.edu.ua/files/Navchal'na\%20robota/Akredytacia/ osv.\%20progr.\%20fizk.\%20bakf.pdf (in Ukrainian)

18. Regulations on organization and conduct of current and final control and mechanism of appealing against the results of students. [document on the Internet]. Accepted by Academic Board of Lviv State University of Physical Culture. 2019. [cited 2021 Jan 12]. [cited 2021 Jan 12]. Available from: https://www.ldufk.edu.ua/files/tekst_fail/dokumenty $\% 20$ LDUFK/oskarzhennja\%20rezultativ\%20navchannja\%20 04\%2020.pdf (in Ukrainian)

19.Provisions on scholarship support for students, postgraduates, doctoral students. [document on the Internet]. Accepted by Academic Board of Lviv State University of Physical Culture. [cited 2021 Jan 12]. Available from: https://www.ldufk.edu.ua/files/Nauka/Studentska\%20nauka/ polozhennia\%20kinc.pdf (in Ukrainian)

20.Soper HE, Young AW, Cave BM, Lee A, Pearson K. On the distribution of the correlation coefficient in small samples. Appendix II to the papers of "Student" and R. A. Fisher. A co-operative study. Biometrika, 1917; 11 (4): 328-413. https://doi.org/10.1093/biomet/11.4.328

21.Bonett DG, Wright TA. Sample size requirements for Pearson, Kendall, and Spearman correlations. Psychometrika, 2000; 65: 23-28. https://doi.org/10.1007/bf02294183

22. Walsh JE. Bounded Probability Properties of KolmogorovSmirnov and Similar Statistics for Discrete Data. Annals of the Institute of Statistical Mathematics, 1963; 15 (1): 153-158. https://doi.org/10.1007/bf02865912

23. Social Science Statistics. [document on the Internet]. [cited 2021 Jan 12]. Available from: https://www.socscistatistics. com/

24.Excel help \& learning. [document on the Internet]. [cited 2021 Jan 12]. Available from: https://support.microsoft.com/ en-us/excel

25.Zanevskyy I, Zanevska L. Models of intra- and interclass correlation test mean-score reliability. Journal of Testing and Evaluation, 2017; 45 (6): 1853-1861. https://doi.org/10.1520/JTE20140363

26.Aghdasi MT, Nasiri M. Motivations and to notify its relationship with socioeconomic conditions of male and female participants in public exercises in the city of Tabriz. World Applied Sciences Journal, 2012;17 (1): 109-112.

27.Chan YK, Chen S, Tu KW, Chi LK. Effect of autonomy support on self-determined motivation in elementary physical education. J. Sport Sci. Med. 2016; 15: 460-466.

28.Arias-Estero JL, Castejon FJ, Yuste JL. Psychometric properties of the intention to be physically active scale in primary education. Rev. Educ. 2013; 362: 485-505. https://doi.org/10.4438/1988-592X-RE-2013-362-239

29.Gillison FB, Rouse P, Standage M, Sebire SJ, Ryan RM. A meta-analysis of techniques to promote motivation for health behaviour change from a Self-Determination Theory perspective. Health Psychol. Rev. 2019; 13: 110-130. https://doi.org/10.1080/17437199.2018.1534071 


\section{Information about the authors:}

Ihor Zanevskyy; (Corresponding author); https://orcid.org/0000-0002-9326-1167; izanevsky@ukr.net; Department of Informatics and Kinesiology, Lviv State University of Physical Culture; Lviv, Ukraine.

Lyudmyla Zanevska; https://orcid.org/0000-0001-9279-2372; Izanevska@ukr.net; Department of Economics and Management, Lviv State University of Physical Culture; Lviv, Ukraine.

Cite this article as:

Zanevskyy I, Zanevska L. Academic and sport achievements of the physical culture and sports university students. Pedagogy of Physical Culture and Sports, 2021;25(3):165-171.

https://doi.org/10.15561/26649837.2021.0304

This is an Open Access article distributed under the terms of the Creative Commons Attribution License, which permits unrestricted use, distribution, and reproduction in any medium, provided the original work is properly cited (http://creativecommons.org/licenses/by/4.0/deed.en).

Received: 02.12.2020

Accepted: 22.01.2021; Published: 30.06.2021 